\title{
Beyond the Billingas: From Lay Wealth to Monastic Wealth on the Lincolnshire Fen-Edge
}

\author{
John Blair
}

Barbara Yorke's manifold contributions to Anglo-Saxon history-in her books, articles, lectures and ubiquitous conference appearances-have never lacked chronological or thematic breadth. A notable strength of her work is an emphasis on the largely undocumented 6th century as a historical period in its own right, determinative of critical changes in the 7 th. She has also done more than most to illuminate the immediately pre-Christian and secular contexts of early monastic life. I hope she will like this case-study in continuity, which illustrates how the spectacular but ultimately transient religious culture of the later $7^{\text {th }}$ to $9^{\text {th }}$ centuries rested on older socio-economic and territorial foundations.

It also considers a part of England (once tackled by Barbara herself in a magisterial survey article $)^{1}$ which even for the age of Bede is largely undocumented, and which therefore demands creative use of the fast-growing archaeological record. To explore what was going on during c.6oo-85o in the dynamic and prosperous 'eastern zone', 2 comprising the east midlands, Norfolk, Lincolnshire and south-east Yorkshire, encounters special challenges that are not always fully acknowledged. On the one hand, that region provides most of our physical evidence for buildings, settlements, coins, pottery and other artifacts. On the other hand, it is almost completely deficient in written sources of a kind that might illuminate conditions at a local level. That makes the temptation to extrapolate from Kentish and West Saxon laws, or the charter archives of major churches in other parts of England, hard to resist. Yet there are grounds for suspecting that those texts describe societies of a significantly different kind: less wealthy at grassroots level, less dynamic, more hierarchical.

It is that combination of material richness with archival poverty that makes the $7_{\text {th- to }}$ th-century archaeology of the region so controversial. Eastern

1 Barbara Yorke, "Lindsey: the lost Kingdom Found?" in Pre-Viking Lindsey, ed. Alan Vince (Lincoln, 1993), pp. 141-50.

2 As defined by John Blair, Building Anglo-Saxon England (Princeton, 2018), pp. 24-51, which offers a framework for the present discussion of regionality. 
England abounds in metal-detected (and occasionally excavated) 'productive sites' that yield recurrent sets of metal objects, often displaying prominent Christian symbolism or implying literacy. Some of these places contain or adjoin churches, or occupy topographical settings-notably islands, promontories and river-bends - that have been considered distinctively monastic. Were they inhabited by aristocrats with a strong interest in ecclesiastical material culture, or by high-living ecclesiastics? Is it really possible that monastic communities were so thick on the ground in eastern England? ${ }^{3}$

Although East Anglia has been the main focus of this debate, the most prolific settlement of this kind so far recognized was at Flixborough, in northwestern Lindsey near the Humber estuary. The present study looks at a region of Kesteven, on the southern Lincolnshire fen-edge, that has not produced an assemblage of this kind (though it does contain the most coin-rich 'productive site' in England), and has not figured in the minster debate. It is, however, in the virtually unique position of being documented: it is the subject of the only genuine pre-Viking legal text that unambiguously relates to a specific place in Lincolnshire, Norfolk or Suffolk (S 1440 [AD 852]). ${ }^{4}$ Moreover, its archaeological record has filled out in recent years, notably for the immediately premonastic era. In combination, these sources make it possible to reconstruct an unusually coherent picture, which may offer lessons for the minster debate in other parts of eastern England.

\section{The Billingas and Before: Ethnic and Social Identity, 40o-65o}

This study concerns a fifteen-mile stretch of the fen-edge in central-east Kesteven, confronting the peat fen where it surrounds the west corner of the Wash (Fig. 19.1). The landscape is low-lying, with a mixed geology of limestones, mudstones, tills and glacial sand and gravel. The eastern edge towards the fen is heavily dissected with inlets, alternating with occasional islands of mainly glacial deposits. In the early middle ages, however, the (almost certainly) Romano-British Car Dyke constituted an emphatic man-made division between inhabited land and fen.

3 For some recent views: John Blair, "Flixborough Revisited," ASSAH 17 (2011), 101-07; Christopher Loveluck, Northwest Europe in the Early Middle Ages (Cambridge, 2013), pp. 124-42; Andrew Tester et al., Staunch Meadow, Brandon, Suffolk, East Anglian Archaeology 151 (Bury St Edmunds, 2014), pp. 377-93.

4 S 1804 and 1805 (AD 675×92) probably refer to Repton, not Rippingale; S 1412 (AD 786×96) may refer to Swineshead in Bedfordshire, not Lincolnshire: see S.E. Kelly, ed., Charters of Peterborough Abbey, Anglo-Saxon Charters 14 (Oxford, 2009), pp. 183-85, 205. 


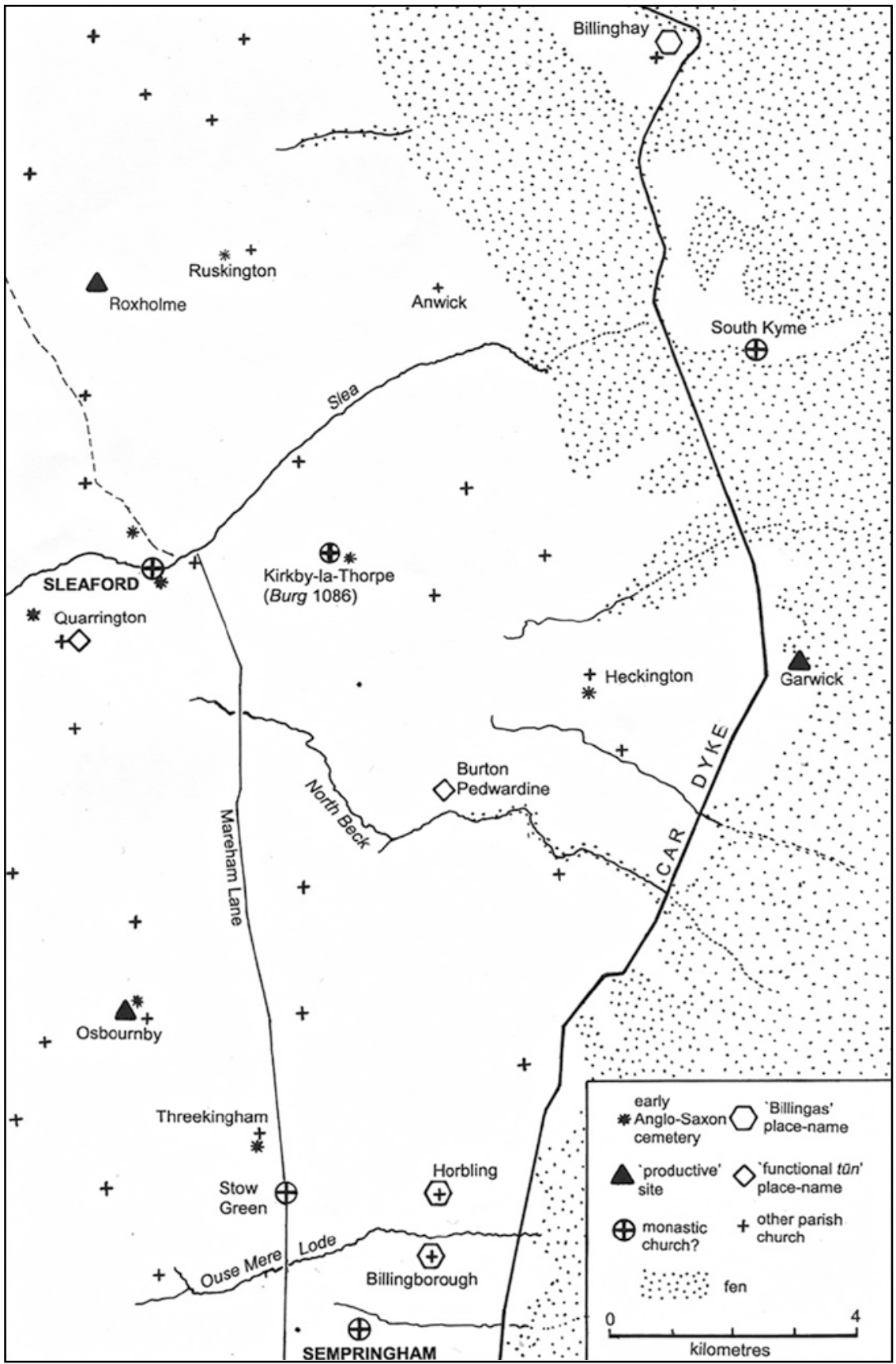

FIGURE 19.1 The land of the Billingas: south-east Lincolnshire and the fen-edge, showing places mentioned in the text 
The early Anglo-Saxon archaeology of this zone has been reviewed by Caitlin Green, in her study of post-Roman Lincolnshire. ${ }^{5}$ Green makes a powerful case for a long-term coherence and identity through the late Romano-British to early Anglo-Saxon eras, apparent in finds of post-Roman British items and in concentrations of cremation and inhumation cemeteries. For present purposes, we may especially note the large cremation cemetery at Quarrington near Sleaford, and a scatter of inhumation cemeteries running southwards from Ruskington via Sleaford to Folkingham. Green comments:

The sense, derived from their distribution and separation from the other cemeteries of northern Kesteven, that the Ruskington-SleafordFolkingham group of cemeteries may represent a genuine early AngloSaxon 'settlement unit' and territory, is heightened by a closer examination of the archaeology of this part of northern Kesteven. ${ }^{6}$

That archaeological perspective gains support from a trio of 'folk-group' placenames running down the fen-edge: Billinghay, Horbling and Billingborough. These incorporate the name of an extended kindred, the 'Billingas, ${ }^{7}$ and their close proximity to the self-contained funerary landscape of the cemeteries is suggestive. Whether or not the Billingas should be identified with the "Bilmigas' of the Tribal Hidage (Green concludes, with prudent though possibly slightly excessive scepticism, that they should not), they look broadly comparable to the other territorially-defined groups in the Middle Anglian section of that text. ${ }^{8}$

This combined evidence points to a stable and long-term social identity. At some point - presumably in the 6th or 7 th century - the inhabitants, though probably of mixed Brittonic and Anglian origin, made that identity explicit by associating themselves with an eponymous Billa and his following. To some extent, this strong territorial coherence would have evolved naturally from the distinctness of their geographical niche, along the eastern and seawards-facing side of the zone between the Trent and the Wash. Beyond that, though, it must have been heightened by the economic possibilities of that location. There

5 Thomas [Caitlin] Green, Britons and Anglo-Saxons: Lincolnshire AD 400-650 (Lincoln, 2012), especially pp. $60-77,128-37,170-202$, is the source for this section except where otherwise stated.

6 Green, Britons and Anglo-Saxons, p. 187.

7 Green, Britons and Anglo-Saxons, p. 40 and n. 41.

8 Cf. Green, Britons and Anglo-Saxons, pp. 185-86. Given the probably convoluted transmission of the Tribal Hidage, an amendment of 'Bilmigas' to 'Billingas' does not seem implausible to me. 
were strong incentives to harness means of production and exchange: the opportunity was there to become extremely rich.

\section{Exchange and Wealth: The Background to the High Monastic Era}

The fen-edge was a crucial but in some ways self-contained zone in the economy and society of Anglo-Saxon England. ${ }^{9}$ The hagiographer Felix, writing c.720-40, famously pictured the "most dismal fen of immense size, [...] now consisting of marshes, now of bogs, sometimes of black waters overhung by fog, sometimes studded with wooded islands and traversed by the windings of tortuous streams. ${ }^{10}$ This dismissive language belies the archaeological message that the coastal strip had a dynamic role in food-production, and as an interface with economies of the North Sea zone, which must have made it very significant indeed for high-consuming Mercian elites. The fen-edge communities are likely to have had their own strong sense of identity, ${ }^{11}$ but it may have been one defined more by the seaways eastwards than by English neighbours westwards.

Socially distinctive or not, the Billingas people were not isolated economically. Green writes of the Sleaford burials:

$[\mathrm{T}]$ his cemetery was not only exceptionally large, but also exceptionally well connected to the outside world. Thus, for example, many more amber beads - around 981 in total — have been found in the Sleaford cemetery than in any other Anglo-Saxon cemetery in England, these being mainly used in the sixth century and probably imported from the Baltic. Similarly, there is a notable concentration of walrus- or elephant-ivory rings in the Sleaford cemetery, and this cemetery has also produced more

$9 \quad$ Andy Crowson, Tom Lane, Keith Penn and Dale Trimble, Anglo-Saxon Settlement on the Siltland of Eastern England, Lincolnshire Archaeology and Heritage Reports 7 (Heckington, 2005); Katherina Ulmschneider, "Settlement, Economy and the 'Productive Site': Middle Anglo-Saxon Lincolnshire AD 650-780," Medieval Archaeology 44 (2000), 53-79, at pp. 70-71.

10 Felix, Vita Sancti Guthlaci, chapter 24, ed. Bertram Colgrave, Felix's Vita Sancti Guthlaci (Cambridge, 1956), pp. 86-87: "Est in meditullaneis Britanniae partibus inmensae magnitudinis aterrima palus, ... nunc stagnis, nunc flactris interdum nigris fusi vaporis laticibus necnon et crebris insularum nemorumque intervenientibus flexuosis rivigarum anfractibus."

11 For the distinctive perceptions of coastal communities see Aidan O'Sullivan, "Place, Memory and Identity among Estuarine Fishing Communities: Interpreting the Archaeology of Early Medieval Fish Weirs," World Archaeology 35:3 (2003), 449-68. 
than twice as many probably imported crystal beads (again, primarily a sixth-century artefact) as any other Anglo-Saxon cemetery. ${ }^{12}$

How did this material arrive? Thanks to the work of Adam Daubney and Michael Metcalf, one entry-point for luxuries is now known with confidence. Two miles east of Heckington village, and immediately beyond the Car Dyke, is a spur of high ground projecting from the fen-edge. Its name 'Garwick', recorded from the thirteenth century, probably means 'trading-place (wic) of triangular shape. ${ }^{13}$ The Anglo-Saxon items metal-detected there comprise fourteen artefacts from the 6th century, 23 artefacts from the 7 th to mid-9th centuries, 26 gold tremisses of $c .570^{-670}$, some 240 sceattas from $c .715^{-50}$, and just three post-750 pennies. ${ }^{14}$ This quantity of coins is phenomenal, surpassing any other 'productive site' in England; to put the gold coins in context, the Portable Antiquities Scheme (PAS) database for the whole of Lincolnshire contains just one further example. While they raise questions as well as answering them (notably the odd disjuncture between the tremisses up to 670, which are from Frankish mints but excluding Frisia and Dorestad, and the sceattas after 715, which are heavily Frisian and dominated by Dorestad), they point to a massive in-flow of wealth, presumably in exchange for English exports such as wool and perhaps slaves. ${ }^{15}$

For transport along the fen-edge, it is possible that the Car Dyke was still significant. Both the original and the post-Roman functions of this man-made channel are debated: was it a drain, a canal or a boundary? The detailed and admirably open-minded survey published in 2005 avoids definitive conclusions, but vindicates the canal option as plausible: "Whatever the purpose of the Car Dyke, it would serve, when completed, as a means of local transport."16

12 Green, Britons and Anglo-Saxons, p. 191.

13 For a recent discussion of minor wic names see Blair, Building, pp. $255-56$. Field-boundaries at Garwick do indeed suggest a triangular area, with sides of $c .250 \mathrm{~m}$., bisected by the road from Heckington to Swineshead Bridge.

14 Adam Jonathan Daubney, Portable Antiquities, Palimpsests and Persistent Places: A MultiPeriod Approach to Portable Antiquities Scheme Data in Lincolnshire (Leiden, 2016), pp. 228-48; D.M. Metcalf, "Tremisses and Sceattas from the South Lincolnshire Productive Site," British Numismatic Journal 86 (2016), 96-117.

15 Metcalf suggests that the tremisses may have been brought by Gallic slave-traders. That is certainly plausible, but it should perhaps not be taken for granted that these coins came direct from Francia, rather than at second-hand through more northerly intermediaries.

16 Brian B. Simmons and Paul Cope-Faulkner, The Car Dyke: Past Work, Current State and Future Possibilities, Lincolnshire Archaeology and Heritage Reports 8 (Sleaford, 2004), p. 163 . 
There is no evidence that it remained navigable in the early to middle AngloSaxon period, nor that it did not. Valuable corridor as it was between Lindsey in the north and Middle Anglia in the south, the natural (if not currently the usual) assumption may well be that the effort of keeping it clear of silt was always thought worthwhile.

Garwick must surely have been the point of interface between North Sea traders and the leaders of the Billingas, who could have organized transport of goods along the Car Dyke both northwards and southwards from the wic: it helps to explain the exotic 6th-century luxuries at Sleaford, and also perhaps why those luxuries were concentrated in a minority of rich graves. ${ }^{17}$ (Intriguingly, the three places with Billingas-related names are all within a mile of the Dyke.) In the 8th century, the sceattas show that participation in the Frisian commercial nexus continued at least up to the collapse of that currency. Despite the lack of broad pennies, it is not impossible that Garwick remained an economic node through the era of Mercian dominance: some of the silver items date from well into the gth century.

Another economic 'persistent place' lay in the south-west of the territory, at Osbournby. ${ }^{18}$ Here the time-span is even longer: the metal assemblage is dominated by Romano-British material, and continues through the late- and postmedieval periods. Artefact distributions of the 6th to 11th centuries (and later) show a strong spatial continuity. The items are also more typical than at Garwick, comprising the now-familiar mixture of strap-ends, hooked tags, pins and occasional coins - but lacking the styli and inscribed items that have become recognized signatures of putatively ecclesiastical sites. If Garwick hints at concentration and control, Osbournby reminds us that the economy in this rich zone of England is unlikely to have been monopolistic or commanddriven. Rather, long-standing material prosperity gave scope for mutually advantageous interactions between grassroots communities and proprietorial elites, whether those elites were defined in terms of kindreds, warrior prowess, or the new monastic culture. Whoever was in charge, a place like Osbournby was always there.

Before we examine how ecclesiastical topography mapped onto the topography of kinship, proprietorship and commerce, a basic point needs to be made about all of them: this was a world of 'central clusters', not complex centres. ${ }^{19}$ Before 1oth-century urbanization, structured activities in the AngloSaxon landscape were not based on concentrated, multi-functional places, but

17 Green, Britons and Anglo-Saxons, p. 191.

18 Daubney, Portable Antiquities, pp. 120-79.

19 For this argument see Blair, Building, pp. 193-201. 
on constellations of linked points with complementary functions. Some of the problems and concerns that arise from a later perspective are therefore irrelevant: we do not need to identify the secular centre, or the main church, but rather to establish which settlements, installations and churches were attached to which others. That is an institutional question, which conventionally requires written evidence, but it also has topographical dimensions that can leave their imprint on the landscape. In eastern England, that is usually all we have. In the present case, it is instructive-notwithstanding the unique survival of a document - to see first what can be made of the non-written evidence on its own.

Topographically and archaeologically, it is apparent that the Billingas region had two core nodes. These display a certain symmetry: they lie on the same Roman road, each of them contains a probable pre-monastic secular focus, and each includes ecclesiastical sites and possessions. We will approach them through the physical and onomastic evidence before turning to the unique testimony of S 1440, a mid-gth-century Medeshamstede charter.

\section{The Northern Cluster: Sleaford, Quarrington, Kirkby-la-Thorpe and South Kyme}

The topographical and archaeological focus of the northern part of the territory is the complex settlement of Sleaford (Fig. 19.2). ${ }^{20}$ This was itself divided in two by the alluvial river-valley of the Slea, including Sleaford Fen immediately west of the town. North of the river, the supposed 'planned town' of New Sleaford and its parish church are now known to have Anglo-Saxon origins: in particular, a group of rectilinear though rather flimsy structures excavated immediately west of the church are tentatively dated to the 8 th or 9 th century. ${ }^{21}$ At Holdingham, just outside the town to the north-west, an apparently sizeable settlement in the 5 th- to 8 th-century range has recently been located; Roxholme, slightly further north, was reported to be producing sceattas, pins, mounts and other eighth-century items as this paper was going to press. ${ }^{22}$

20 Sources for this section, except where otherwise stated, are: Christine Mahany and David Roffe, eds., Sleaford, South Lincolnshire Archaeology 3 (Stamford, 1979); Sheila M. Elsdon, Old Sleaford Revealed, Nottingham Studies in Archaeology 2 (Oxford, 1997).

21 Mahany and Roffe, Sleaford, pp. 20-27. This dating is implied by the presence of shelly wares combined with the absence of Stamford Ware.

22 P. Cope-Faulkner, "Archaeological Evaluation on Land at Lincoln Road, Holdingham, Sleaford, Lincolnshire," unpublished evaluation report, Archaeological Project Services Rep. 110/o6 (Sleaford, 2006); Roxholme finds reported by Adam Daubney, May 2018. 


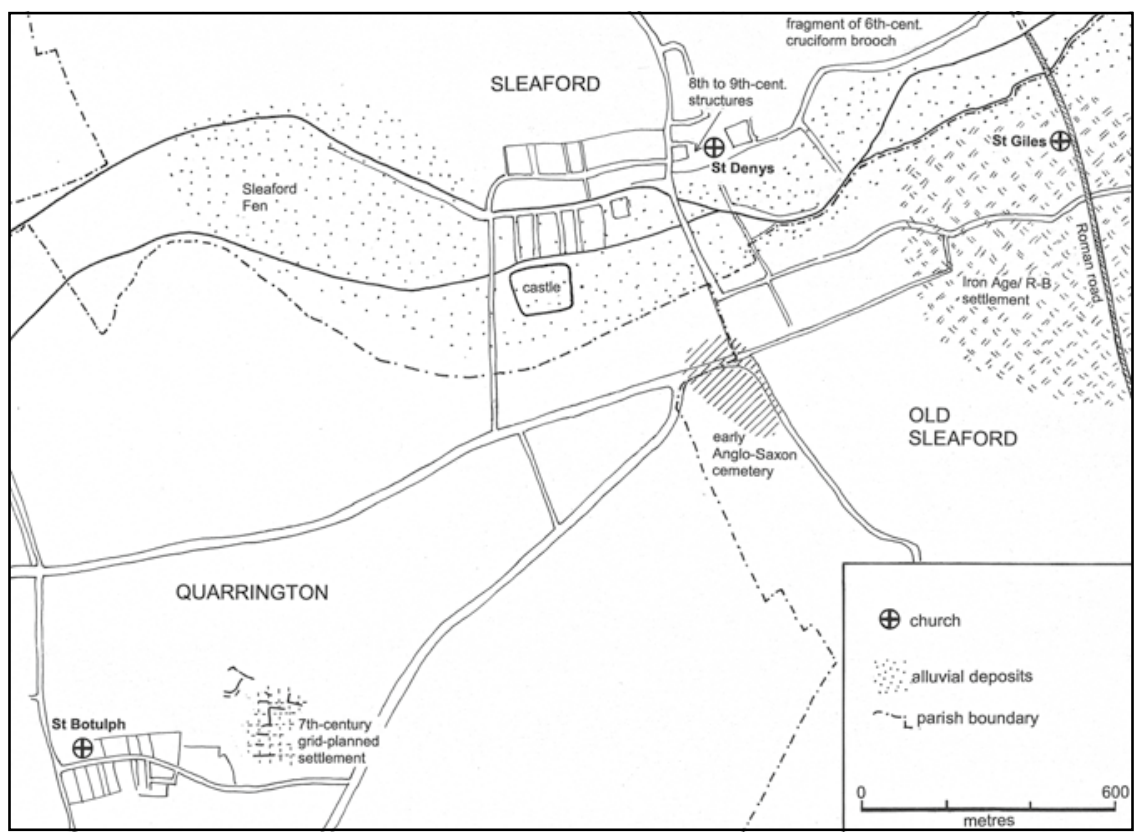

FIGURE 19.2 The historic core zone of Sleaford and Quarrington, showing sites mentioned in the text

Currently more impressive, however, is the material from south of the river, including the large late Iron Age and Roman settlement at Old Sleaford (bisected by Mareham Lane, the Roman road from Durobrivae near Peterborough to Lincoln) and the rich 6th-century cemetery mentioned earlier. At Quarrington, to the south-west, a complex settlement spanning the $5^{\text {th }}$ to 8 th centuries was excavated in the early $1990 \mathrm{os}^{23}$

Lincolnshire is rich in settlement sites of the middle Anglo-Saxon period, and the Sleaford material of that date does not stand out as exceptional. Nonetheless, there are some indirect pointers to its special status. One is its formation around the burial focus of the 6th-century community, which clearly was exceptional in its day. Another is the collocation of three churches: St Denys's (probably the Bishop of Lincoln's church at Sleaford in Domesday Book) north of the river, St Botolph's at Quarrington and St Giles's at Old Sleaford (probably the two Domesday churches of Quarrington) south of the river. ${ }^{24}$

23 Gary Taylor et al., "An Early to Middle Saxon Settlement at Quarrington, Lincolnshire," AntJ 83 (2003), 231-80.

24 GDB fols. 344v, 346v; Mahany and Roffe, Sleaford, pp. 13-14, 17. 
A more concrete indicator comes from the Quarrington excavation, where a configuration of 7 th- to 8th-century ditches seems to have been laid out using the technique of formal grid-planning. Recent research shows that this practice in pre-Viking England was especially associated with the monastic high culture, and it raises the possibility that Quarrington was some kind of monastic dependency. ${ }^{25}$ The place-name (cweorning tūn, 'millers' settlement') strengthens that possibility, since it is of a classically 'functional' type and suggests that this was a specialized dependency of some centre. Given the close tenurial links, that centre can scarcely have been other than Sleaford, which was a major grain-processing site later. ${ }^{26}$

One further comment in the Quarrington excavation report is worth quoting:

The range and variety of fabrics indicate that Quarrington had access to an extensive trading network. In the Early Saxon period, the fabrics at Quarrington are known to have come from southern, northern and central Lincolnshire as well as from Leicestershire. By the Middle Saxon period the source of the vessels was mainly the Northamptonshire area, with a smaller element from south and central Lincolnshire as well as a few sherds from Ipswich. Contact with the Lindsey part of Lincolnshire at this date seems very limited, with only four vessels from the area being found on the site. ${ }^{27}$

This southwards re-orientation of Quarrington's economic links has implications to which we will return.

Two miles east of Sleaford is the village of Kirkby-la-Thorpe (Chirchebi in Domesday Book). There has been a consensus that the distinctive Old Norse compound kirkja-by $(r)$ reflects, in one way or another, the local presence of an important church in existence by the time of the Viking settlements. ${ }^{28}$ Most recently, Tom Pickles's careful analysis (focused on Yorkshire but with wider implications) identifies two alternative meanings: 'church-farm' in the sense of a daughter-house or cell of a minster containing its own church, and 'farm

25 John Blair, "Grid-Planning in Anglo-Saxon Settlements: the Short Perch and the FourPerch Module," ASSAH 18 (2013), 18-61, at pp. 31-34; John Blair, Stephen Rippon and Chris Smart, Planning in the Early Medieval Landscape (Liverpool, 2020).

26 Simon Pawley, "Grist to the Mill: a New Approach to the Early History of Sleaford," Lincolnshire History and Archaeology 23 (1988), 37-41.

27 Taylor et al. "Early to Middle Saxon Settlement," 276.

28 John Blair, The Church in Anglo-Saxon Society (Oxford, 2005), pp. 310-11, and works cited. 
of the church' in the sense of an estate belonging to a religious community. ${ }^{29}$ In practice these meanings shade into each other, and in either case it seems likely on topographical grounds that the parent community was Sleaford.

One further site, manifestly ecclesiastical on artistic evidence, could have been part of the Sleaford complex, though the closest topographical analogy points in another direction. South Kyme is a sand and gravel island in the peat fen, facing the outflow of the River Slea. The existing parish church is part of an Augustinian priory founded in 1169, but it contains fragments of an exquisite panel-built stone chest or shrine from the late 8th or early gth century. This has stylistic links with the 'Haedda Stone' at Peterborough (Medeshamstede), and with other Mercian sculpture at Breedon, Fletton and Castor. ${ }^{30}$ A strikingly close parallel is the whalebone Gandersheim Casket-essentially a miniaturized version of the kind of composite shrine that the South Kyme fragments represent—of which Leslie Webster has written:

[It] reveals this artistry [the Mercian animal style] at its subtlest and most exquisite. ... One of its creatures, with a prancing posture and pointed wing, appears in identical form on a sculptured stone fragment at Castor, near Peterborough, suggesting that the same model was used for both. It therefore seems plausible that the casket ... was made at the great monastery of Medeshamstede. ${ }^{31}$

South Kyme church, then, had a context in the high monastic and cultural milieux of late 8th-century Mercia. It does not look important in any other way, ${ }^{32}$ unless the 12th-century Augustinian foundation (or re-foundation?) reflects the kind of 'submerged continuity' that Tim Pestell has identified at a large number of East Anglian monastic sites. ${ }^{33}$

29 Thomas Pickles, Kingship, Society and the Church in Anglo-Saxon Yorkshire (Oxford, 2018), 244-45.

$30 \quad$ P. Everson and D. Stocker, Corpus of Anglo-Saxon Stone Sculpture, 5: Lincolnshire (Oxford, 1999), pp. 248-51 and ills. 339-45.

31 Leslie Webster, Anglo-Saxon Art (London, 2012), pp. 106-8, 140-2.

32 However, Adam Daubney informs me (pers. comm.) that quantities of Middle Anglo-Saxon material have recently been metal-detected from a field near Anwick, some 3 miles (5 $\mathrm{km})$ wNw of South Kyme: is this another significant wic name like Garwick?

33 Tim Pestell, Landscapes of Monastic Foundation: The Establishment of Religious Houses in East Anglia, c.650-120o (Woodbridge, 2004), pp. 194-99, 216-17, 219-22. He identifies a recurrent congruity of site, even though direct continuity is not demonstrable in most cases. Whatever the reasons for this pattern (Pestell's term 'continuity of retrospection' may be helpful), it clearly has lessons for the present cases of South Kyme and Sempringham. 
The location of South Kyme on an island at the mouth of the Slea might encourage speculation that this was an outlying hermitage or retreat-house of Sleaford, analogous to the 'remoter houses' known to have belonged to Lindisfarne, Lichfield, Hexham and Melrose. ${ }^{34}$ But did the shrine celebrate a local hermit comparable to St Guthlac, whose tomb-on the fen-edge island of Crowland near Medeshamstede - was adorned with 'wonderful constructions of ornaments built by King Æthelbald'? 35 Topographically and geologically, the relationship between Sleaford and South Kyme bears close comparison to the relationship between Medeshamstede and Crowland. That raises a different possibility: Guthlac and his hermitage at Crowland were free-functioning, and not dependent on Medeshamstede. On the other hand, the sculpture constitutes a strong suggestion that, by c.80o, Medeshamstede had laid its hands on South Kyme. If ecclesiastical patronage operated in several stages, there may have been a broad trend from pluralism to more hierarchical and centralized arrangements.

\section{The Southern Cluster: Threekingham/Stow Green and Sempringham}

The focus of the southern part of the territory includes the suggestively-named Billingborough, 'the burh of the Billingas', and Horbling, 'the Billingas' muddy land'. While these names cannot be precisely dated or contextualized, they speak of a time when the Billingas themselves were still a reality, or at least an important memory. A large inhumation cemetery at Threekingham is poorly recorded, but a late 18th-century report mentions skeletons found "with a deal of rusty iron." ${ }^{36}$ Although the evidence is less direct, therefore, this could have been a 6th- to 7 th-century secular node comparable to the one at Sleaford.

Two miles west of Horbling, the almost empty landscape around Stow Green near Threekingham (again on the Roman Mareham Lane) belies that site's august and saintly associations in the 11th century. As David Roffe and Rosalind Love have shown, Ely traditions identified Stow Green as 'Ædelreðestowe', where St Æthelthryth (d. 679) broke her journey through Lincolnshire and where a chapel (identified from finds of burials and grave-marker fragments) was built in her honour. ${ }^{37}$ This story is, of course, far from contemporary, but it occurs early enough to suggest an established pre-Conquest tradition; the element stōw is a familiar indicator of a significant religious site. A fair held there on St Æthelthryth's feast in 1275 (and possibly recorded in

\footnotetext{
34 Blair, Church, pp. 217-18.

35 Felix, Vita S. Guthlaci, chapter 51, pp. 162-63.

36 Audrey Meaney, Gazetteer of Early Anglo-Saxon Burial Sites (London, 1964), p. 165.

37 David Roffe, "The Seventh Century Monastery of Stow Green, Lincolnshire," Lincolnshire History and Archaeology 21 (1986), 31-33; R.C. Love, ed., Goscelin of Saint-Bertin; the Hagiography of the Female Saints of Ely (Oxford, 2004), pp. xv, xlii, 46.
} 
Domesday Book) gains significance in the context of the widespread associations between minsters and markets. ${ }^{38}$

Sempringham, 2 miles ( $3.2 \mathrm{~km}$ ) south of Stow Green, is well-known for a different reason. Its Priory, which developed from an eremetical community founded c.1131, was the mother-house of the Gilbertines, the only Englishfounded religious order. ${ }^{39}$ At that point Sempringham already possessed a parish church (of which St Gilbert, the founder of the order, was priest), and this survives as St Andrew's church, located in a group of rectilinear enclosures north of the Priory site. In 2005, an intensive geophysical survey and programme of field-walking was carried out, to assess plough-damage and clarify the topography of the Priory and its environs. ${ }^{40}$ One unexpected outcome was the discovery that an area measuring some 300 by 200 metres, around and west of the parish church and mostly within the ditched enclosures, was strewn with 6th- to 9th-century pottery, including Ipswich- and Maxey-type wares with a central date-range of $c .720-820$.

This indicates a significant settlement concentration of relevant date, but the nature of the settlement remains unclear. No metal-detector survey was conducted, so it is unknown whether or not the distinctive metal items that characterize monastic-type sites in the 'eastern zone'-and the absence of which we have noted from Osbournby-were present too. In the light of Pestell's East Anglian model, though, the juxtaposition of this site with the first Gilbertine priory looks suggestive. The suggestion of continuity is encouraged by the later pottery at Sempringham, which implies unbroken occupation through the gth to 12 th centuries and beyond.

\section{The Era of Monastic Insecurity: Mercian Power and Secular Predation}

During the century after $75^{\circ}$, monastic patronage and endowment suffered a progressive, ultimately catastrophic reversal. Lay magnates clawed back what

38 Roffe, "Seventh Century Monastery," p. 31; Ulmschneider, "Settlement, Economy and the 'Productive' Site," p. 73 .

39 Brian Golding, Gilbert of Sempringham and the Gilbertine Order, c.1130-c.1300 (Oxford, 1995), pp. 13, 198-202.

40 G. Coppack and P. Cope-Faulkner, "Sempringham Priory: Survey and Assessment of the Mother-House of the Gilbertine Order and the Tudor Mansion that Replaced it" (unpublished paper); P. Cope-Faulkner, ed., "Assessment of Fieldwalking and Geophysical Survey at Sempringham Priory and Village, Pointon and Sempringham, Lincolnshire," unpublished, APS Report 113/o8 (2008). Many thanks to Glyn Coppack for providing a copy of this report, and for helpful discussions. 
their ancestors had given, and minsters became pawns in strategies for investment, land-management, administration and defense. ${ }^{41}$ Those pressures would have been as heavy in south-east Lincolnshire-important both economically and strategically to the ascendant Mercian regime-as anywhere else. The Billingas zone offered access from the Trent corridor to the traderoutes and commercial riches of the Wash catchment; ${ }^{42}$ it was also close to Ermin Street, which must have figured in any Mercian scheme to exert control over East Anglia and Lindsey.

What might such a scheme have looked like? That question has been explored elsewhere in relation to the Mercian polity as a whole, ${ }^{43}$ with broad conclusions that suggest some possibilities when applied to this local example. Very briefly, it seems that Mercian rulers achieved joined-up government and civil defence through series of nodes - often strung out along navigable rivers and land-routes - that each comprised a royal enclosure or compound ringed by specialized and dependent service complexes. Nomenclature is important here: the relevant place-names are surprisingly consistent, and suggest an 'administrative' vocabulary imposed from above. ${ }^{44}$ The nature and appellations of the centres varied, but the satellites generally had names in -tūn. Especially characteristic is the compound implying dependence on a fortification (burh) that usually comes through to us as Burton, Bourton or Berrington: it seems that a burh-tün was a specific and consistent entity, providing surveillance functions for its parent burh and extending its viewshed across surrounding terrain. ${ }^{45}$

In some sense, the centre to which a burh-tün belonged was by definition a burh, and that element often-though by no means always-occurs in its place-name. ${ }^{46}$ It may therefore be relevant that each of our two nodes contains a burh name. When the name 'Billingborough' was formed is impossible to know, though it could potentially have been as late as the Mercian era. In the Sleaford node, we can perhaps be a little more precise. As David Roffe has shown, a lost Domesday place called Burg was part of Kirkby-la-Thorpe, and had its own (now-lost) church of St Peter additional to Kirkby's church of

\footnotetext{
41 Blair, Church, pp. 121-34.

42 Cf. Blair, Building, pp. 180-82, 220.

43 Blair, Building, chapter 6.

44 Blair, Building, pp. 193-94.

45 Blair, Building, pp. 199-201.

46 Blair, Building, pp. 200-01, noting that in the names of former Roman places with burhtūn adjuncts, the 'functional' descriptor burh often over-rides the 'archaeological' descriptor ceaster.
} 
St Denis. ${ }^{47}$ This juxtaposition of a burh with a kirkja-bỳ $(r)$ is intriguing: it implies at least two layers of naming, of which burh-being English rather that Norse-is perhaps likely to be the earlier. If the cyric acknowledged in the Norse name was Sleaford minster or an outlying component of it, does the burh represent an intermediate, later 8th-century stage when that component was assimilated to the Mercian defensive system?48

In support of this line of speculation is the fact that Burg had its burh-tūn: Burton Pedwardine, 2.5 miles ( $4 \mathrm{~km}$ ) SSE of Kirkby village, which appears as Burtun in Domesday Book. The distance between centre and satellite, and the resemblance of this configuration to several others including both Roman roads and burh-tün places, ${ }^{49}$ are so consistent with the general pattern as to leave little doubt that the relationship is real and purposeful. ${ }^{50}$ That might in turn help to clarify the date when - as noted above-the name Quarrington (cweorning tūn) was formed as a functional dependency of Sleaford. There are grounds for thinking that the functional generic tūn is pre-eminently a later 8th- to gth-century formation. ${ }^{51}$ So even if Quarrington had been a monastic dependency for a century or more, it may have acquired its present name in the same era as Burton Pedwardine, when the Sleaford complex was starting to feel burdened by the military and provisioning requirements of the Mercian crown.

Moving on a stage, from the height of the Mercian regime under Offa to its trauma under Burgred, we at last confront the text that is such a remarkable survival in its regional context. It belongs to a distinctive 9th-century category of vernacular agreements and dispute-settlements concerning land, the formulations of which can be somewhat clumsy and impenetrable. In that

47 David Roffe, “The Lost Settlement of Burg Refound?" unpublished but accessible online at http://www.roffe.co.uk/burg.htm.

48 Compare the change of the name of Medeshamstede itself to Peterborough, 'St Peter's burh', which could have happened in a context of Mercian royal domination: Kelly, Charters of Peterborough, pp. 37-40.

49 Blair, Building, pp. 201-19, especially the cases of Margidunum, Littleborough and Dorchester.

5o A potential weakness in this argument is that Burton Pedwardine and Kirkby-la-Thorpe villages are not intervisible. Both, however, are intervisible with the (perhaps significantlynamed) Beacon Hill between them. In any case we do not know precisely where Burg lay: if it was in the south-east of Kirkby parish (below the 10-m contour) it would have been visible from Burton, which also has clear views north-eastwards towards Heckington, Garwick and the fen-edge.

$5^{1} \quad$ Blair, Building, pp. 194-97. 
respect $S 1440$ is no exception, but with the help of Susan Kelly's edition and insightful commentary some important data can be extracted. ${ }^{52}$

The document records an agreement made in $85^{2}$ between the religious community at Medeshamstede/Peterborough and a lay magnate called Wulfred. Medeshamstede leases "the land at Sempringham" to Wulfred and one next heir, who are to hold it for renders of firewood, so that "he may enjoy the full freedom of the land at Sempringham and at Sleaford in perpetuity" (Jet he Jes landes fulne friodom bigete in ece cerfeweardnesse cet Sempingaham and cet Slioforda). Medeshamstede is to enjoy the land at Sleaford; Wulfred is to enjoy that at Sempringham, in return for specified renders of food, drink, horses and money, and after the deaths of him and his heir it is to revert to Medeshamstede. At that stage a further 20 hides will be transferred to the Medeshamstede community for their refectory, and 12 hides at Forde (unidentified) and Cheale (near Gosberton) to the 'lord' of Medeshamstede; conversely, 2 hides at Lehcotum (unidentified) will be transferred by Medeshamstede to Wulfred's kin.

This complicated transaction leaves some unanswered questions, the most important being the previous status of the Sleaford land: was it originally Wulfred's (making this an exchange of two valuable assets), or originally Medeshamstede's (implying an attempt by the community there to get the best out of a bad situation in which a powerful layman had encroached on their property)? Kelly's tentative preference is for the former interpretation, ${ }^{53}$ but the wider context offers grounds for favouring the latter. This agreement, like others of its kind and era, shows an eminent and previously secure religious community embroiled in the ultimately hopeless struggle to protect its assets against the tides of fortune: Wulfred, whoever he was, ${ }^{54}$ was a man with whom they had to compromise on a playing-field that was not level. It is all too easy to envisage a situation in which he or his family had annexed both these estates from Medeshamstede during the unstable decades since 820, necessitating a deal by which he could be persuaded to restore them-one immediately, the other posthumously-in return for a handsome payback. (In the event, there is no evidence that either property was ever again possessed by the Medeshamstede/Peterborough community.)

What leaps out from this text, in the light of the argument so far, is that the two specified 'lands'-Sempringham and Sleaford-correspond to the two core nodes of the Billingas territory. That fact, combined with the testimony of

$5^{2} \quad$ Kelly, Charters of Peterborough, pp. 215-21.

53 Kelly, Charters of Peterborough, p. 218.

54 Probably a Mercian thegn who attests several royal diplomas: Kelly, Charters of Peterborough, p. 219 . 
the South Kyme sculpture, supports the view that the two estates had been linked in Medeshamstede's possession in the medium past, and also perhaps further back. But another imponderable is the precise status of the entities defined as 'Sempringham' and 'Sleaford': were they simply possessions, or monastic communities in their own right? The conventional Old English term land tells us nothing specific, but it certainly does not exclude monastic identity. By that stage it had become commonplace to describe old religious communities and their endowments as measures of land, and in some texts that practice is explicit. 55

Those analogies do not in themselves entitle us to define the two centres named in the $85^{2}$ lease as monastic. They do, however, chime happily with the other cumulative if mainly indirect indicators that that was indeed the case. Taken together, the evidence is quite persuasive that slices of the Billingas territory had been assigned to support two monastic establishments there during the late 7 th- to early 8 th-century boom in endowment, and that over the next century or two those establishments suffered the pressures common in such cases. The survival of the lease offers a rare opportunity to compare a sample of the highly-developed but essentially prehistoric 'eastern zone' with the documented zones outside it, and to observe a gth-century trajectory that was essentially similar.

\section{Conclusion}

The density of ecclesiastical sites in this modestly-sized tract of land must, at some level, reflect its established prosperity. Wealth consisted not just in hidages, but in productive capacity and economically advantageous contacts: the opulence of the Sleaford cemetery and the Garwick productive site were the underpinning of later monastic initiatives.

The inferred minsters at Sleaford and Sempringham could have been controlled by Medeshamstede from a relatively early date, perhaps even from their foundations. A possible pointer in that direction is the economic re-orientation away from Lindsey and towards Northamptonshire suggested by the Quarrington pottery. ${ }^{56}$ However, the traditions associated with Threekingham and

55 Blair, Church, p. 130. A good parallel for the Sleaford-Sempringham text is an agreement between Ealdorman Ælfred and the Christ Church, Canterbury community in the 87os or '80s (S 1202): Christ Church leases to Ælfred "the land at Croydon," but Croydon is explicitly called a minster in 809 (S 64).

56 Cf. Daubney, Portable Antiquities, pp. 247-48; it seems very likely that the pottery was carried northwards along the Car Dyke. 
Stow Green complicate the picture, suggesting as they do that St. Æthelthryth's community at Ely may also have had a stake in the early monastic development of the region. Likewise, the possibility is open that South Kyme was originally independent of both Sleaford and Medeshamstede. It could well be that Sleaford and Sempringham (and indeed Threekingham and South Kyme) began as autonomous foundations by the local 7 th-century leaders-presumably endowed out of the family lands of the Billingas or their successors-and were progressively drawn into the ambit of the dominant fen-edge communities further south.

Any such transactions are beyond the reach of surviving documents, and it is worth pausing to ask why that should be so. The 'eastern zone', which in material terms was the richest in 8th-century England, is to all intents and purposes prehistoric, and we are not entitled to assume that the social and legal norms of other regions-for example bookland-ever took root there. It is a commonplace that Viking devastation destroyed all the early charters. However, the later fenland monasteries did preserve some pre-Viking material, and there is no obvious reason why that should not have included diplomas. In any case, there is no reason at all why they should not have preserved 1oth-century royal diplomas if such existed. In fact, not a single reliable pre-Viking royal diploma, ${ }^{57}$ and only three reliable 1oth-century ones (all from Edgar's reign), ${ }^{58}$ relate to places in the entire region of Lincolnshire, Norfolk and Suffolk. Was this a society of rich, independent freemen who recorded transactions as vernacular agreements and memoranda, and amongst whom the concept of royally-conferred bookland gained little traction?59 Like the regional contrasts in material remains, that possibility reminds us that 'Anglo-Saxon England' was not a homogeneous entity, but an amalgam of often contrasting culture-zones.

By the mid-8th century, Medeshamstede's stake in the Billingas territory may have helped to strengthen Mercia's tightening grip; the South Kyme sculpture, probably a Medeshamstede product, is testimony to 'imperial' Mercia at its most sophisticated and splendid. Offa seems to have held Medeshamstede and its abbot Botwine in esteem, but it was a relationship that came with

\footnotetext{
57 Above, n. 4.

$5^{8}$ S 703 (Chelsworth, Suffolk, AD 962), S 781 (Stoke near Ipswich, Suffolk, AD 970), S 782 (Barrow-upon-Humber, Lincs., AD 971).

59 Bede, of course, famously decried the proliferation of bookland grants in Northumbria. But he does not tell us whether the practice was general through that kingdom, or specific to parts of it. Bede, "Letter to Bishop Ecgbert," chapter 12, ed. Christopher Grocock and Ian N. Wood, Abbots of Wearmouth and Jarrow (Oxford, 2013), pp. 146-49.
} 
obligations. ${ }^{60}$ One such may have been the burdening of Sleaford with royal defensive installations, a burh and its burh-tūn. The demands of kings and their powerful magnates become increasingly insistent from $c .790$ onwards, ${ }^{61}$ culminating in negotiations of the kind implied by the Sleaford-Sempringham agreement. It may well be that when the first Viking raiders arrived, those monastic settlements were already mere shadows of their former selves.

That leaves unclear the precise extent of ecclesiastical land-holding at its height. The range of possible interpretation remains wide, but it has its limits. In broad terms it is hard to doubt that by, say, $75^{\circ}$ the monastic presence in this small strip of the fen-edge was quite significant, and we can make tentative steps towards quantification.

The 'Bilmigas' are assigned 600 hides in the Tribal Hidage, though since the identity of that group with the Billingas is disputed, the fact is of doubtful relevance, Still, the Billingas territory as reconstructed from the place-names looks comparable to the Middle Anglian peoples comprising the nucleus of the Hidage, whose territories are typically assessed in the range from 300 to 900 hides. Unfortunately, where the two main properties are concerned, the $85^{2}$ lease gives no hidages that can be compared with this broad order of magnitude for the parent territory. However, the fact that the lesser estates used as make-weights at the end of the agreement comprised 20, 12 and 2 hides respectively suggests that the principal assets in contention were much bigger than that. It is far from implausible that the main Sempringham and Sleaford landblocks were each in the order of 50 to 100 hides, or even more. ${ }^{62}$ We can therefore reasonably infer that monastic endowment had eaten up a significant slice of the former territory of the Billingas. Furthermore, the complex nuclei known by the names of the two focal settlements must have controlled at least some sections of the valuable fen-edge, including by implication the church site at South Kyme with its lavish sculpture, and perhaps also the plutocratic node at Garwick, which the sceatta finds show to have continued into the likely era of monastic lordship.

Even if we err towards caution, Sempringham and Sleaford were hugely valuable assets: no wonder that the pressures towards secular control and lordship proved too strong for their monastic proprietors to resist. The main fact to set against a maximal hypothesis of monastic domination in the region is the absence (so far) of rich cruciform objects, styli, and the other now-familiar indicators of the 'minster culture'. But that could reflect different circumstances

$60 \quad$ Kelly, Charters of Peterborough, pp. 17-20.

61 Kelly, Charters of Peterborough, pp. 19-20.

62 Cf. the cases listed by Blair, Church, p. 87. 
of survival and retrieval. Sleaford is a built-up town, and the field survey at Sempringham did not include metal-detecting. The Quarrington site, which was extensively excavated, had a simple material culture, suggesting its status as a service dependency. ${ }^{63}$ Future work should show whether the apparent concentration of rich finds from this region at secular sites (Garwick and Osbournby) rather that ecclesiastical ones is an effect of retrieval, or shows something genuinely different from the pattern at Flixborough and the East Anglian sites. At all events the South Kyme fragments show that, by $c .800$, the region had access to ecclesiastical art at the highest level.

That problem notwithstanding, the case-study may have some lessons for undocumented regions of Lincolnshire and East Anglia where sites producing ecclesiastical-type metalwork are so thick on the ground. The Sleaford and Sempringham complexes were zones of linked sites, each two to three miles across, with only three or four miles between them. Similar monastic landscapes could easily be inferred in many parts of Norfolk, for instance, even though there are no texts to help us resolve them into clusters with named centres. In Anglo-Saxon England, as in other societies at other times, the monastic boom was an immensely powerful cultural and spiritual force while it lasted, and devotees invested lavishly. ${ }^{64}$ When resources would stretch to it, the impact of that investment on the landscape could be remarkably close-grained. ${ }^{65}$

63 Compare a similarly-planned settlement next to Ely: R. Mortimer, R. Regan and S. Lucy, The Saxon and Medieval Settlement at West Fen Road, Ely: The Ashwell Site, East Anglian Archaeology 110 (Cambridge, 2005).

64 Cf. Blair, Church, pp. 73-78, 84-91.

65 For comments on an earlier draft, I am very grateful to Kanerva Blair-Heikkinen, Glyn Coppack, Adam Daubney, Ryan Lavelle, and Kevin Leahy. 